Article

\title{
Product Diversification in Sustainability Transition: The Forest-Based Bioeconomy in Finland
}

\author{
Jukka Luhas $^{1, *}$, Mirja Mikkilä ${ }^{1} \mathbb{D}$, Ville Uusitalo ${ }^{2}$ and Lassi Linnanen ${ }^{2}$ \\ 1 Sustainability Science, School of Energy Systems, LUT University, FI-53851 Lappeenranta, Finland; \\ mirja.mikkila@lut.fi \\ 2 Sustainability Science, School of Energy Systems, LUT University, Saimaankatu 11, 15140 Lahti, Finland; \\ ville.uusitalo@lut.fi (V.U.); lassi.linnanen@lut.fi (L.L.) \\ * Correspondence: jukka.luhas@lut.fi
}

Received: 21 May 2019; Accepted: 12 June 2019; Published: 14 June 2019

\begin{abstract}
The forest-based bioproduct field has diversified into the chemical, medical, energy, nanoproduct, and construction material sectors. This paper argues that forest-based bioeconomy has kept the focus on conventional products and new bioproducts have primarily been developed as extensions to existing product portfolios due to a lock-in mechanism, i.e., a state where an economy gradually locks itself to a dominant market position due to technical interrelatedness, economies of scale, and quasi-irreversibility of investment. The study examines forest-based product transition in the context of lock-in mechanisms through narrative analysis over the past 170 years. A theoretical framework is formulated based on complex system studies and the economics of lock-in mechanisms. The relation between the lock-in mechanisms of the regime and product diversification is described for the forest-based bioeconomy in Finland. The study supports previous findings indicating that interactions occur between the lock-in mechanisms. Furthermore, lock-in mechanisms can have a neutral, adverse, or beneficial effect on product diversification. The paper extends knowledge about the role and functioning of lock-in mechanisms in changing market environments. Recent trends in network development and foreign investment, and their effects on industrial symbiosis and product diversification, is recommendable to consider in future research.
\end{abstract}

Keywords: sociotechnical transition; systemic transition; forest industry; pulp and paper industry; wood processing; path dependence; lock-in; increasing returns; value addition

\section{Introduction}

Transition to a sustainable bioeconomy is one of Europe's responses to the key environmental challenges of climate change and resource depletion [1]. A robust bio-based industrial sector will reduce dependency on fossil-based products, support climate targets, and lead to sustainable growth [2]. Currently, the bioeconomy accounts for around $4 \%$ of the gross domestic product (GDP) of the European Union (EU) [3] and around 16\% of the GDP of Finland [4]. The backbone of the Finnish bioeconomy, the forest-based bioeconomy, is formed by the pulp and paper industry (PPI) and the wood processing industry, but also increasingly the energy and chemical industries. Cooperation with other industries, such as the machine industry and the packaging industry, has created unique technologies, know-how, and solutions, and has made Finland a forerunner in bioeconomy development [5]. In relation to its size, Finland is more dependent on its forest and the forest-based bioeconomy than any other country in the world: bioeconomy-related exports account for more than $20 \%$ of export earnings. In addition, the bioeconomy creates welfare through employment effects, especially in sparsely populated regions [6]. 
A successful forest-based bioeconomy in Finland requires a user-driven approach, innovations, and initialization of new technologies, as well as competitive production costs [7]. Such technological and product-related changes can increase the added value of products, improve employment, and help achieve targets set out in the Finnish Bioeconomy Strategy and global climate change agreements. In recent years, structural change in the PPI has driven pulp production investments towards regions with the lowest raw material prices and production of finished paper products closer to major markets [8]. In Finland, this development has led to a $43 \%$ decrease in the number of people employed in the sector (approximately 32,000 jobs) [9], a 40\% decrease in value added in forest-based production [10], a 17\% increase in wood usage [10], and almost tripled pulp exports [11]. Current investment plans envisage 23 million $\mathrm{m}^{3}$ wood capacity in pulp and energy production and, if realized, wood usage will grow by approximately $34 \%$ [12]. However, it has been forecast that with an assumption of $2 \%$ productivity increase annually, 30\% of jobs are in the sector are threatened by 2035 [13]. This may slow down the development of sustainable economy, e.g., economic, environmental, and societal equilibrium are not realized.

Biomass is utilized in traditional forest-based bioproducts, such as sawn goods and paper, but also in textiles, medicines, chemicals, functional groceries, plastics, cosmetics, intelligent packaging, and bio-based oils [5]. The emergence of an international trend for greater and more varied usage of bioproducts has been discernable in recent decades. In Finland, however, despite many statements by business leaders to the contrary, diverse use of wood and value addition have not been achieved on a large-scale $[10,14]$, and trust in a closed-network structure and the domination of the bulk production strategy have kept currently prevailing industry structures intact [15]. Lock-in arises through the utilization of technologies and technological systems that follow a specific path and are challenging and expensive to escape [16]. Technological and system lock-in can slow the emergence of alternative and innovative technological solutions [17]. This paper argues that forest-based bioeconomy lock-in in Finland has kept the focus on traditional products and new bioproducts have primarily been developed as extensions to existing product portfolios [18].

Research on sustainability transition has focused mainly on the energy, transport, and agriculture sectors, and less attention has been devoted to other domains. Nevertheless, a number of lock-in cases have been examined in the forest-based bioeconomy sector, for example, as regards regional innovation policy [19] and technology and market shifts [20]. Studies on sociotechnical transitions have tended to focus on the notion of system innovation, and thus there is scope for greater consideration of the topic of regime transformation [21]. The concept of regime as used in sustainability transition studies imposes a path and logic for incremental sociotechnical change along established pathways of development [22]. Transition in a complex system is a result of coevolution at different scales where various domains and their components interact: an economy changes in the short-term, whereas technology changes slowly over a longer time scale [23]. By increasing returns, cumulative path-dependent processes [24] reinforce that which gains success or exacerbate that which suffers loss, which can cause economic lock-in $[25,26]$. Recent studies in sustainability transition research have examined transition through lock-in mechanisms $[27,28]$ and have investigated product diversification $[29,30]$. Lock-in mechanisms and related phenomena such as learning effects, economies of scale, and network externalities [27] can reinforce market position [29]. On the other hand, even though diversification may be required, sociotechnical lock-in that favors dominant designs can hinder the development of alternatives [30] which may be excluded merely because they do not fit the prevailing paradigm [28]. Despite its importance, the relation between lock-in mechanisms and product diversification in a bioeconomy context has received only marginal attention in the literature. Diversity offers systemic robustness, flexibility, and the qualities of precaution that are central to long-term sustainability [31].

This paper investigates the interconnection of the lock-in mechanisms of regime and their relation to product diversification in the forest-based bioeconomy in Finland from 1850-2019. First, the theoretical and operative framework is presented. The material and methods used are then described, followed by examination of product diversification and lock-in mechanisms (economies of scale, learning economies, 
and network effects) in the Finnish forest-based bioeconomy. The paper concludes by discussing the results and presenting conclusions.

\section{Theoretical Framework}

The following section describes the theoretical and operative framework of this paper. First, complex systems are introduced based on systems theory, followed by description of regimes in sociotechnical transitions. Then, the concepts of path dependence and lock-in are presented, followed by lock-mechanisms. Finally, the theoretical framework is operationalized.

Systems theory transcends technological problems and demands, and it investigates all conceivable connections abstracted from concrete situations or experimental knowledge [32,33]. It is the language of theory but does not give the content [33]. Systems theory has become a soft systems approach that has evolved from deterministic to probabilistic and integrated descriptions [23]. It can provide understanding of complex systems [34] and, within the context of a set of understandings of the behavior, the theory investigates the behavior of complex systems that are stable for a long time, and order and intersperse with short times of instability [23]. Complex systems are path-dependent and often nonergodic open systems where diverse nonlinear components interact and evolve: feedback loops occur and a small stimulus can have a significant effect or no effect at all [23,34]. The networks between the components of the system can be seen as a memory that stores and records the recent past of the system [34].

Sustainability transitions determine how sociotechnical systems transform to more sustainable production and consumption through long-term coevolution processes that embody changes in technologies, markets, user groups, infrastructure, science, culture, and regulation $[22,35]$. One of the most essential concepts of transition research, the sociotechnical regime, originates from studies of technological regimes and combines findings of evolutionary economics and the multilevel perspective (MLP) [22]. In the sociotechnical regime, a set of rules are embedded in the know-how, engineering practices, corporate and government structures, manufacturing processes, and product characteristics that are linked and coevolved [36] in different subregimes, such as the technological, user and market, science, policy, and sociocultural regimes [37]. Change can be radical due to the emergence of a new paradigm or continuous along trajectories that are specific to the particular regime [38,39]. A bulk production regime operates under diminishing returns, whereas knowledge-based production operates under a scheme of increasing returns [26]. Innovation is mostly incremental in existing regimes, because of path dependence and lock-in mechanisms, but change still emerges although it is relatively predictable and occurs in particular directions [40].

Path dependence and lock-in have roots in studies of evolutionary economics that explain technological change through technological paradigms, trajectories, and regimes [39,40]. Early studies of path dependence and lock-in examine temporally remote events and increasing returns for adoption by positive feedback loops that can cause the economy to gradually lock itself into a specific outcome [25,41]. The iconic QWERTY case explains how the keyboard type locked-in to a dominant market position due to technical interrelatedness, economies of scale, and quasi-irreversibility of investment, even though an alternative, DVORAK, had better performance [41]. Historical development is highlighted as path-dependent processes [25] whose outcome is conceptualized as lock-in that explains how the technologies coevolve with social, institutional, cultural, and political systems and resist change towards alternative sociotechnical systems [42]. Technological lock-in occurs in forms such as a dominant design, standards in technological architectures and components, as well as required compatibility [43]. A dominant design is one that competitors and innovators follow, and dominant designs arise when the product innovation phase is superseded by process innovation and lower cost phases in the Abernathy-Utterback model [44].

In an increasing returns process, or self-reinforcing or positive feedback process, or lock-in mechanism, the benefits of a current activity increase over time, i.e., switching to an alternative option becomes increasingly costly [45]. Increasing returns can affect predictability, efficiency, 
flexibility, and ergodicity, where specific patterns of timing and sequencing have a critical role $[25,45]$. Increasing returns to scale can lock industrial economies into specific structures, e.g., fossil fuel-based energy systems [17]. Increasing returns occur from four main mechanisms: economies of scale, learning effects, adaptive expectations, and networks effects [46]. Economies of scale increase when higher capacity utilization from large production runs lowers set-up and fixed costs [46,47]. Learning effects occur when knowledge that is gained from use and repetition allows understanding of how to improve production $[46,48]$. Technology that first achieves significant advances along its learning curve has a greater likelihood of becoming a dominant approach [49]. Networks effects increase when positive network externalities attract more users [46], which can increase the inertia in demand and lead to clustering of choices [50]. Network effects can hinder the entry of radical technologies that are not part of the dominant technological cluster [16]. An interesting phenomenon is that reduced isolation and increased integration to regional and global markets can intensify selective pressures and reduce diversity [51]. Increasing returns on the demand side are more important, because stronger increasing returns on the supply side typically lower the probability of lock-in [50]. The consequences of network effects are visible, especially when the cost of adoption is high [52].

The sociotechnical regime is used in this work as a central theoretical approach for study of the forest-based bioeconomy in Finland. The regime is complemented by concepts of lock-in mechanisms and complex systems from evolutionary economics and systems theory, as presented in Figure 1.

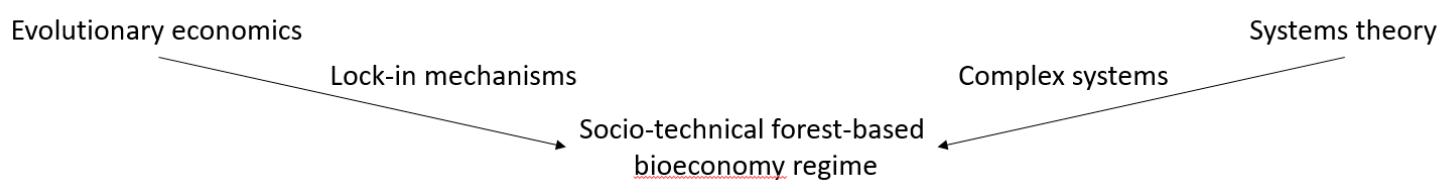

Figure 1. Operative framework of the study.

Complex systems theory provides the foundation for investigation of the Finnish forest-based bioeconomy as a system and understanding of the actors and their interactions. The concept of sociotechnical regime is used to describe the macro environment of the subregimes, e.g., the pulping technology, sawn goods market, and the nanoscience regime, where long-term coevolution processes of the forest-based bioeconomy components have developed. These components and the rules of the forest-based bioeconomy regime operate under lock-in mechanisms that guide change in a certain direction and have an influence on product range. Lock-in mechanisms in relation to product diversification are presented chronologically if possible. This study is limited to three original dimensions of lock-in mechanisms: Economies of scale, network effects, and learning effects. One of the original dimensions of lock-in mechanisms, adaptive expectations, is omitted from the study because it is not considered to be directly applicable to the forest-based bioeconomy, which has long supply chains.

\section{Materials and Methods}

The following section describes the materials and methods used in the study. First, the forest-based bioeconomy in Finland is contextualized. Then, materials are described. Finally, the methodological approach and research design are presented.

Manufacturing of forest-based products has long roots in Finnish history; from tar-burning in the 17th century, to sawmilling [53,54], to pulp and paper production [55], to the diversified bioproduct production of more recent times [56]. Since gaining national independence in 1917, the design, development, and production of wood products in Finland have increased greatly due to technological improvements $[57,58]$ and there have been considerable advances in pulp and paper production $[59,60]$. Production has been fueled, for example, by industrial synergy between the energy and pulp sector, which has allowed exchange between actors in the key areas of energy, water, byproducts, and waste [61]. Cooperative operations have evolved into an influential Finnish forest 
industry cluster [62] that is an important part of the European forest industry [63]. During this transition, companies' strategic actions and focus have varied over time [64]. Competitiveness has been supported by industrial associations [65], national policy priorities, and institutional path dependence within competitive market dynamics [66]. Globalization and EU expansion in the 1990s significantly changed the ownership base of forest products companies [67] and internationalized operations [68], which has had an influence on the Finnish forest cluster [69] and structural change in Finland [9]. In recent years, the, forest-based bioproduct sector has diversified [7] and innovation management has developed to become a part of managerial thinking [70]. Biorefineries are thus seen as a business opportunity [71]. The forest-based bioeconomy is an important part of The Finnish Bioeconomy Strategy and The European Strategy for Growth, but also the United Nations (UN) and the Organisation for Economic Co-operation and Development (OECD) have recognized the potential of a bioeconomy to promote sustainable growth [4].

Within the context described above, an in line with most historical case studies in transition research [22], a qualitative methodology is used in this work. The reviewed material includes domestic and academic literature, reports, statistics, newspaper articles, web pages, and presentations, which are presented in Appendices A and B.

The paper uses a qualitative narrative analysis approach because of its exploratory, fluid, and flexible, data-driven, and context-sensitive characteristics [72]. Narrative analysis as a methodology allows examination of transitions using diverse texts about the history prior to, during, and in the immediate aftermath of the transition, i.e., narratives that refract the past $[73,74]$. Sequence, and consequence make texts narrational because events are chosen for a particular audience [74], and narratives thus require interpretation when used as data [74]. The data is limited for strategic and practical reasons [72] and, consequently, explanations or arguments produced are generalizable only to some extent [72]. Although material is provided for validity judgement [72], there remains a danger of overpersonalization of the narratives [74]. Despite some limitations of the approach, careful research design facilitates logical and rigorous development of the work [72].

In the research design of this paper, as presented in Figure 2, the forest-based bioeconomy framework in Finland is first identified based on the research questions. This study is limited to the forest-based bioeconomy in Finland. Then, relevant material in this framework is collected, preferring academic literature if possible. The time horizon starts from the beginnings of Finnish industrialization in 1850, when the sawmill industry expanded and wood-based pulp production began [75]. The material collected through the operative framework is utilized as input for the analysis. The analysis is divided into the analysis of product selection and lock-in mechanisms based on the research questions. Finally, the results of the analysis are validated. Transparency is promoted by describing the used material and visualization. 


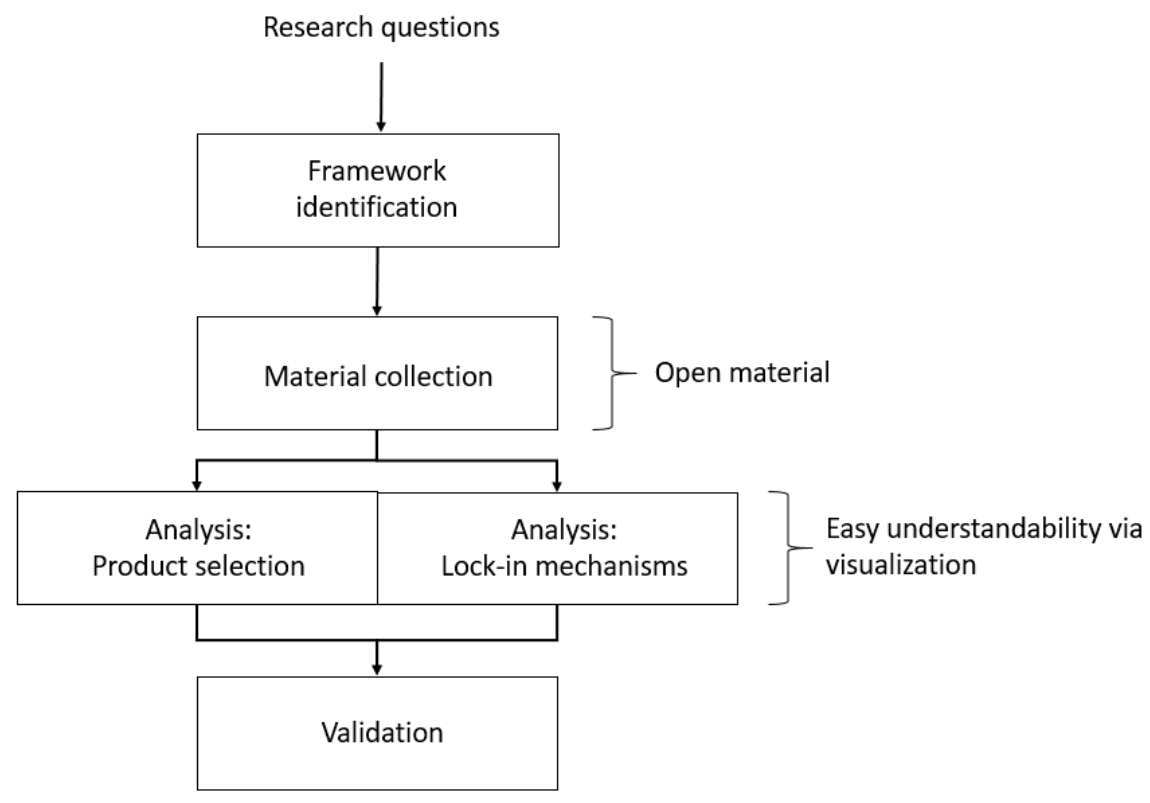

Figure 2. Research design of the paper.

\section{Results}

The dominant trend in the structure of the forest-based bioeconomy regime in Finland since 1850 has been diversification from sawn goods to pulp and paper products (PPP) to high-value bioproducts. The changes appear to follow the Abernathy-Utterback model [44], e.g., lower cost phase in the sawmill, wood panel, and PPI in the 1990s and 2000s [70]. The bioproduct range and industrial symbiosis in the forest-based bioeconomy are presented in Figure 3. The products are presented in chronological order based on when production started. Bold text indicates industrial symbiosis that has influenced product selection. The material on which Figure 3 is based is presented in Appendix B.

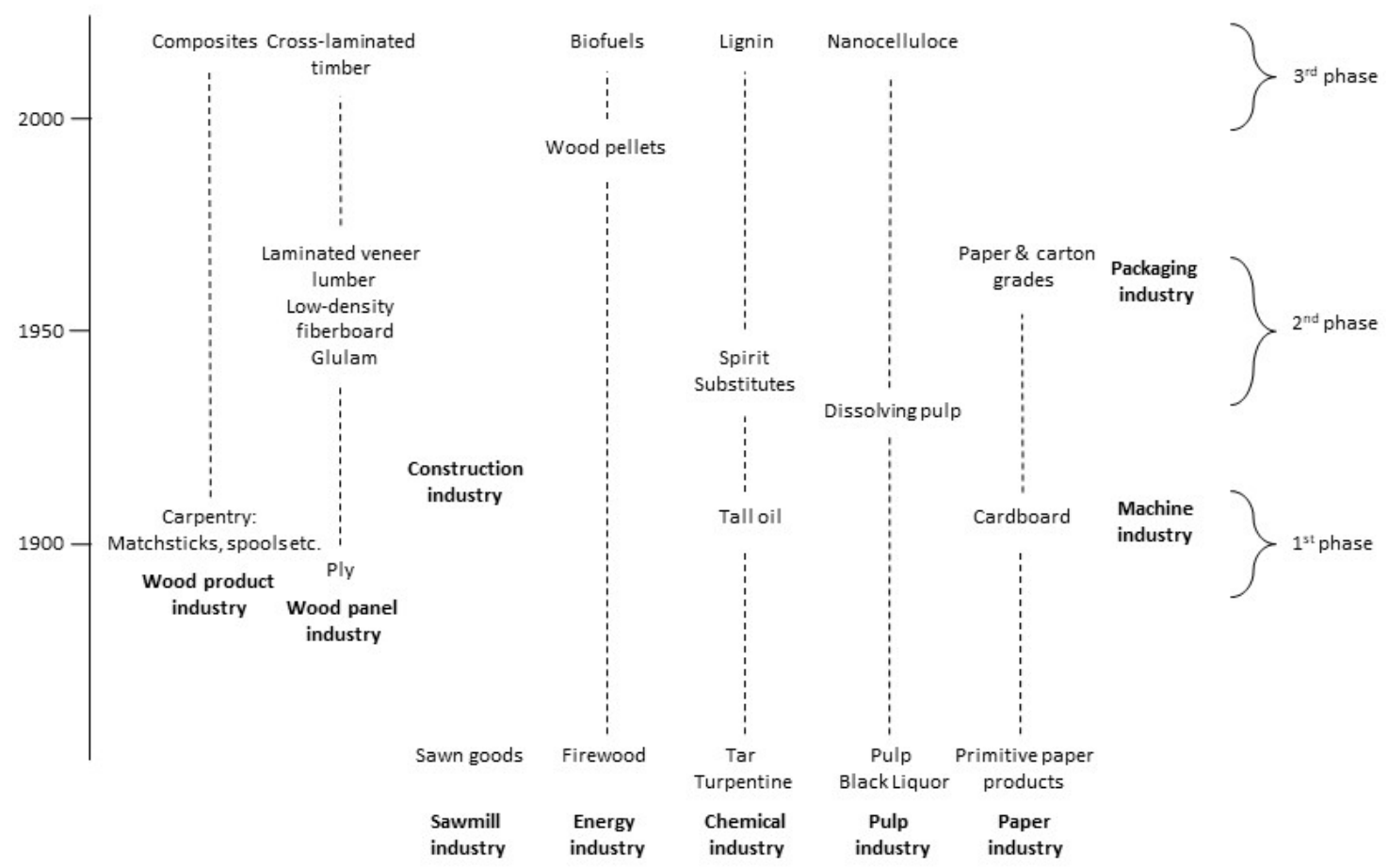

Figure 3. Product range and industrial symbiosis in the forest-based bioeconomy in Finland for 1850-2019 (Appendix B). 
The original product range has diversified in three phases, as can be seen in Figure 3: the first wave of diversification was around the 1900s, the second in the 1950s, and third wave in the 2010s. Industrial symbiosis between the wood processing and machine industries is first found in the product diversification of the 1900s. In the 1950s, war reparations, a trend towards disposable packaging, and office work accelerated cross-industry cooperation: the product range diversified into commercialization of byproducts and related diversification without losing the focus on wood-based products [64]. A new product diversification phase began in the 2010s. It has been broader than earlier, but new robust industrial symbiosis has not yet developed.

\subsection{Learning Effects}

The sawmill industry expanded in the second half of the nineteenth century and wood-based pulp production started in the 1850s [75]. In the late nineteenth century, the industrial dry distilling process of tar production was unprofitable, but the economic viability was improved by use of an oven that also produced turpentine and allowed stump use instead of logs [56,76]. In contrast to tar production, technology always had an important role in the sawmill industry, and technical and skill requirements were high in the PPI [56]. However, prior to Finnish independence in 1917, technological know-how was relatively limited and technology and professionals needed to operate the sawmills and pulp mills were bought from international companies [56].

In the early years of independence, strategic actions of Finnish companies focused primarily on exploitation of forest resources and raw material management [64]. Over time, the quality of research and technical education started to increase and the first journals that focused on technology and the paper and sawmill industry started to be published $[56,65]$. The sawmill industry improved as a result of electrification and improvements in power, blades, maintenance, and artificial drying [58].

After the Second World War (WW2), the strategic focus of Finnish companies changed from raw material extraction and intermediate products to finished product [64]. The shift to higher value products was facilitated by adoption of new technology [66] and in the 1950s and 1960s, the value chain integrated forward from pulp to paper production and from small-scale to large-scale production [77]. Coinciding with this development, emphasis on research and consulting led to specialist know-how developing within the Finnish forest cluster $[53,69,78]$ and companies such as the paper machine producer Valmet became market leaders able to gain competitive advantage from such knowledge [56].

In the 1980s, most investments focused on development of improved paper technology and modernized small-scale PPI production $[64,66]$. Regarding large-scale production, the focus moved towards greater integration as a strategy to address the cyclical nature of the PPI. World-class research was one source of competitive strength [63], and around 90\% of Finnish research and development (R\&D) was spent on PPI [69]. Numerous technical innovations were introduced in pulp and paper production: barking, hacks, conveyors, and storage, but also new process innovations such as the Jylhä, the pressure grinding process, versatile lines, and the medium consistency (MC) pulping technique [60]. In addition, the mechanical wood industry saw improvements in automation: laser equipment, more accurate measurement devices, Röntgen radiation (X-ray) measurements and computerized numerical control (CNC) were introduced [53,57]. However, an innovation paradox was created by the contradiction between short-term cost-efficiency targets and long-term innovation; the forest-based bioeconomy aimed for short-term cost-efficiency and competitiveness [70]. By the early 2000s, all the biggest forest-based bioeconomy companies in Finland ended up with similar outcomes, namely, a focus on paper production [64].

Biorefineries offer new possibilities to diversify business activities [71]. Currently, there is greater emphasis on diversified skills and knowledge, along with greater focus on higher grades of paper and paperboard production [66]. With demand for graphic paper decreasing, the forest-based bioeconomy has undergone a change in strategic direction, which has led to more diversified R\&D [7]. In 2015, the R\&D spending was focused on chemicals (43\%), pulp, paper, and paper products (39\%), construction (12\%), energy ( $4 \%)$, and sawn goods ( $2 \%)$ [13]. 


\subsection{Network Effects}

Finnish tar producers and sawmills became established in European markets in the 19th century [53]. International demand of tar, especially in Europe, was high in the 1880s and Finnish tar accounted for almost half of global production, but at the end of the century, production started to decrease rapidly [56,76]. The sawmill industry created a second wave of forest-based exports, with sawn goods being exported to meet rapidly growing European markets [56]. In the PPI sector, most paper was exported to other parts of the Russian empire [56], but the main market areas changed in the 1900s [64].

One of the most significant changes in the operative environment was the Russian Revolution. Russian markets closed in 1917-1918 and following the cessation of hostilities of the Finnish Civil War, Finnish forest-based bioeconomy companies started to turn to Western markets: Finland became one of the world's biggest sawn goods exporters in the 1920s [55,64]. Access to international markets required cooperation through associations bringing companies together, especially in view of the business structure in Finland at the time, with many small independent manufacturers and suppliers; Finnish companies taken together were a major player on the markets [65]. One of the most important associations, The Central Association of Finnish Woodworking Industries (CAFWI), was founded in 1918. However, the fast-changing economic environment of the time together with prejudices and infighting limited its impact [64,65], and the first rules of association of CAFWI prohibited other societies or associations from joining [65]. The Finnish Paper Mill's Association (Finnpap), founded in 1918, allowed small-scale producers to export to international markets and supported investments [64]. On domestic markets, Finnpap and other bioeconomy associations were, in effect, cartels, and their cooperation led to situations where forest owners received offers from only one purchaser [55]. Finnish forest-based products were exported via marketing associations until the 1990s, which meant that domestic competition was controlled [64].

In the immediate aftermath of WW2, international trade was quite negligible as companies focused on rebuilding their business networks [66,79]. The Finnish economy was directed towards Russian markets due to war reparations, but at the same time, efforts were made to serve Western markets [56]. Industry in Finland recovered quickly as reconstruction, war reparations, and the Korean war increased demand [79]. The institutional environment of the time was highly collaborative and there were few competitive pressures from abroad [66]. Interactive dynamics of organizations gained positive externalities by cooperation and competition in the forest cluster [69]. Clustering within the machine industry accelerated due to war reparations [80].

In the last two decades of the 20th century, around $80 \%$ of exports in the forest-based bioeconomy went to Europe [63]. The focus was on the core countries of the EU: France, Germany, and the United Kingdom [68]. Especially, paper production was fueled by exports [63]. From the 1970s, industrial symbiosis with the machine industry accelerated and paper mill machinery was purchased domestically; Tampella produced grinders, Valmet produced paper machines, and Wärtsilä produced coaters [81]. By the 1990s, machinery and production equipment in the PPI and sawmill industries were largely domestic [63]. In addition, the maturing chemical industry started to reinforce the forest cluster [63]. Changes in Finnish economic policy meant that the role of shareholders became stronger while the operations, as well as ownership base of Finnish forest-based bioeconomy companies, became more international; average foreign holdings increased from a small share to over $50 \%$ of the Finnish forest-based bioeconomy companies by 1999 [67].

Digitalization and changes in behavior began to affect paper and board markets in the early 21st century: paper production in Finland dropped by 45\% between 2004 and 2017 [10,82]. In recent years, demand for pulp, paper, and sawn goods has decreased in Europe, whereas it has increased in Asia, which now accounts for one fifth of export returns [12,83]. A major part of sawn goods ( $33 \%$ of total sawn good exports) and pulp ( $42 \%$ of total pulp exports) with low added value were exported to Asia [12]. 


\subsection{Economies of Scale}

Forest-based bioeconomy production was a home industry until the 19th century, when such dispersed production began to be replaced by greater centralization, which benefitted large-scale production and allowed economies of scale $[54,56]$. Private companies bought millions of hectares of forest area and tried to monopolize forest resources [55].

As a result of industrialization and larger production volumes, integration was considered necessary in order to achieve economies of scale [62]. Vertical integration was part of strategic behavior in the industry from Finnish independence in 1917 until the 1980s [64]. In the vertical integration, parts of supply chain were purchased or established; from forests to international sales organizations [64]. The limits of organic business growth were reached in the 1980s [64]. Horizontal integration was a part of business strategy in the Finnish forest-products industry from independence until the 1990s [64].

In the mid-20th century, renovation and upgrading of production lines and investment in new capacity aimed to make production more efficient both to achieve economies to scale and to increase the added value of products [64].

Mass production, a focus on large production volumes, and low specialization were typical characteristic features of the forest-based bioeconomy [65] of the 1990s and early 2000s, which limited innovation activity [70]. In connection with changes in the overall Finnish business environment, forest products companies set higher targets for return of investment (ROI), and increasing shareholder value became a major target [67].

In the 2010s, the competitive advantage of pulp producers in Finland was based on large-scale, efficient long fibrous pulp production [13]. Substantial foreign investment funding has led to large-scale investment in pulp production $[84,85]$.

\subsection{Summary of the Results}

From the above analysis, it can be seen that interactions between lock-in mechanisms have occurred and the lock-in mechanisms have affected the product range. The results are summarized in Table 1.

Table 1. Summary of lock-in mechanisms in relation to product diversification in the forest-based bioeconomy transition in Finland.

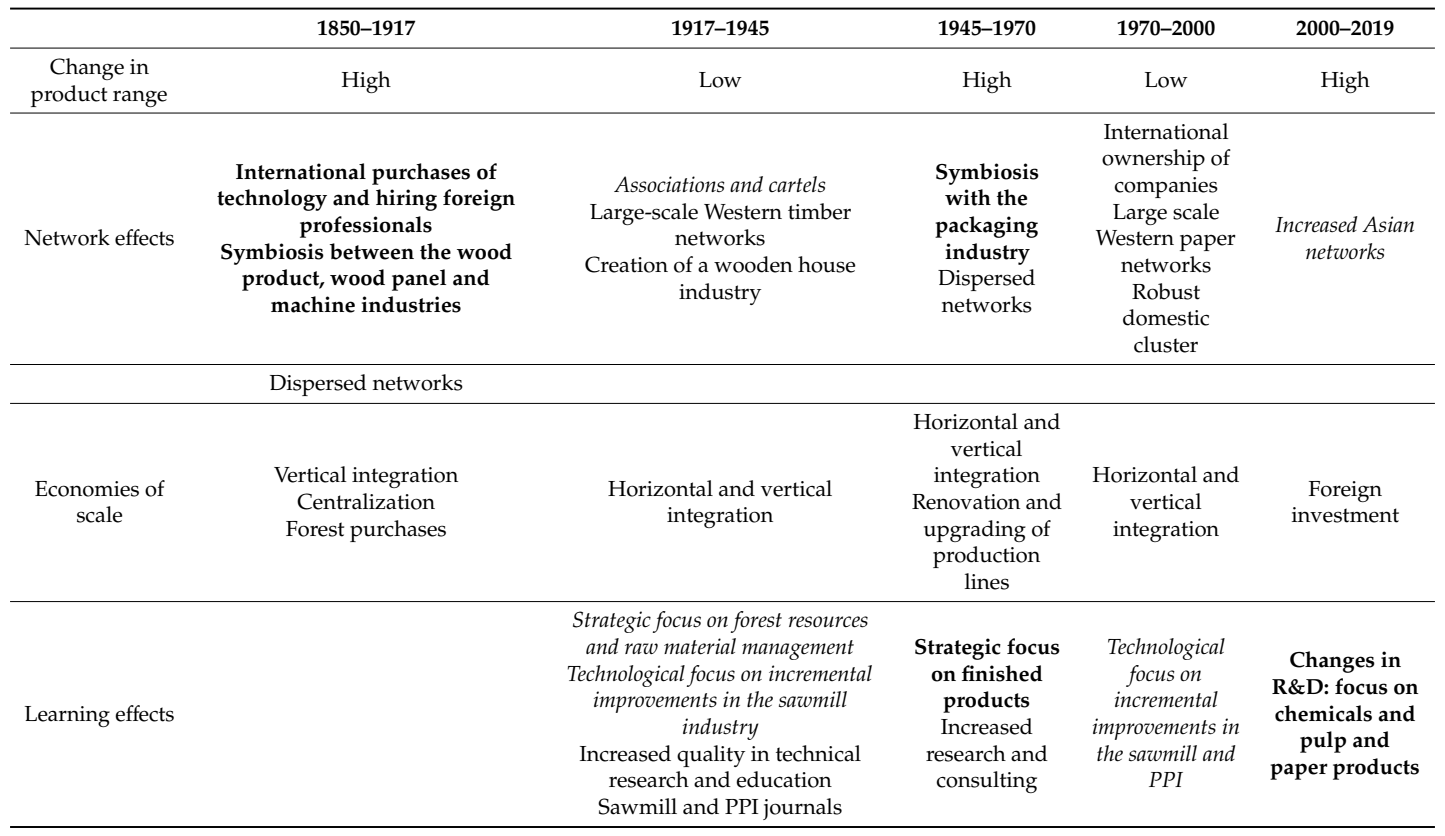

Bold = Beneficial lock-in mechanism effect for product diversification. Italic = Adverse lock-in mechanism effect for product diversification. Normal $=$ Neutral or unidentified lock-in mechanism effect for product diversification. 
Interactions between the lock-in mechanisms have occurred vertically, e.g., foreign investment has increased along with Asian networks, and renovation and upgrading of production lines have targeted higher added value of the products along with the changes in the strategy. In addition, horizontal interactions have occurred, e.g., marketing associations and cartels co-operated with Western timber networks, and international purchases in technology and knowledge allowed symbiosis between the wood product, wood panel, and machine industries.

The lock-in mechanisms have influenced the product range as Table 1 illustrates: Product diversification has occurred as a result of international takeovers, industrial co-operation as well as changes in strategy and R\&D. Product diversification has been hindered by a focus on incremental improvements (innovation paradox), industrial associations and cartels, and a resource-based strategy. Large-scale networks abroad in the dominant design have most likely hindered product diversification, whereas dispersed networks have most likely promoted product diversification.

\section{Discussion}

System lock-in in the forest-based bioeconomy in Finland has resulted in robust group thinking with a narrow perspective of how the industry should operate strategically [66]. A path-dependent business strategy has created the foundation for an operational model that has followed specific technology, products, resources, and international as well as domestic market status [64]. Certain courses of action have been restricted or prevented due to coevolution of the capability base of Finnish bioeconomy companies and the institutional environment [66]. This reciprocity has manifested itself in business privileges, a sense of entitlement among actors in the industry, and state enabling of allowance of intra-industry joint investment, marketing, and R\&D [66]. The forest-based bioeconomy in Finland is an archetypal case of lock-in that shows how path-dependent increase in returns create techno-institutional lock-in that leads to the development of conventional products in a particular and desirable direction.

The number of actors and the linkages between them have increased continuously in industrial symbiosis and correlated production and diversification of products [61]. The significant distance between the firms and their end customers [86] and a focus on the incremental development of process technology and the value chain have caused a reduction in the importance of strong regional clusters [62]. A need for efficient commercialization and marketing of know-how abroad along with active network creation nationally and internationally have been recognized as prerequisites for diversification of business activities [71]. Similarities can be found in nanotechnology, where it has been shown that the degree of clustering can have a negative association with creation of technological diversity [87]. In this sense, industry symbiosis and clustering first influence product diversification beneficially, but as the degree of symbiosis and clustering increases, the effect can change to adverse.

At the regional level, market-related regulatory barriers can limit the development and adoption of radical and path-breaking innovation, which in turn results in limitations in regional innovation policy in the context of locked-in old industrial regions [19]. On the other hand, demands from a large number of industry sectors can split the papermaking development to new development sectors, e.g., the energy, textile, and chemical sectors [20]. Similarities can be found in the Indian software sector, which is highly export-dependent on the US market [88]. The lock-in effect implies neither high productivity nor any particular tendency for innovation [88]. Similar to industrial symbiosis and clustering discussed in the previous paragraph, diverse and dispersed demand can first beneficially influence product diversification, but as the degree of demand increases, the effect can change from beneficial to adverse.

Interactions between different lock-in mechanisms can reinforce or weaken technological trajectories [27]. Coevolution at the regime level is clearly visible [35]. In this sense, a lock-in mechanism that does not affect product diversification directly can have an impact by interaction with other mechanisms, e.g., interaction between foreign investment and new networks. On one hand, the impact may be seen in higher productivity rather than product diversification, because foreign funding of production results in the major share of produced pulp being exported [89]. On the other 
hand, new foreign-funded biorefineries, such as BioFutureFactory [90], and more diverse networks may increase product diversification.

This study is qualitative and exploratory in nature and a number of limitations thus need to be borne in mind. Three major dimensions of lock-in mechanisms were identified and discussed, whereas at least nine different dimensions have been identified [27]. Furthermore, some lock-in mechanisms might be missing due to the long time scale considered.

\section{Conclusions}

Transition in the forest-based bioeconomy in Finland has been influenced by historical events and megatrends such as industrialization, wars, globalization, digitalization, and climate change, which have all had an impact on the product range. Lock-in mechanisms have offered opportunities for maintaining and increasing returns.

The literature of path dependence and lock-in and the used research design are highly relevant in analysis of transition of the forest-based bioeconomy. The effect of lock-in mechanisms in relation to product diversification can be neutral, adverse, or beneficial. Network effects can first have a beneficial influence, which later becomes adverse. In addition, vertical and horizontal interactions can occur between the lock-in mechanisms, which can change the effects on product diversification from neutral to beneficial or adverse.

This research extends knowledge of lock-in mechanisms in the forest-based bioeconomy and offers insights for sustainability transition studies investigating the role of lock-in mechanisms in relation to product diversification. The results are not globally generalizable due to the historical, geographical, and societal specificity of the case; nevertheless, there are similarities with other countries, Nordic countries in particular. It is recommended to qualitatively and quantitatively study lock-in mechanisms of the forest-based bioeconomies in other regions and political systems in order to comprehensively understand the role of the lock-in mechanisms in economic development and sustainable transition. The phenomenon could be studied further in different economic systems with abundant forest resources, for example, within a liberal market economy like Canada, a former transition economy such as Russia, and emerging markets such as China and Indonesia.

Future industrial policy, as well as future research, should take into account the effects of lock-in mechanisms on product diversification in order to achieve all spheres of sustainability. This study adopted a broad-brush approach and considered transition over the long term; future research could investigate recent trends and the effect of networks and foreign investment on industrial symbiosis.

Author Contributions: Conceptualization, J.L. and M.M.; Methodology, J.L and M.M.; Software, J.L.; Validation, J.L. and M.M..; Formal Analysis, J.L.; Investigation, J.L.; Resources, J.L.; Data Curation, J.L.; Writing-Original Draft Preparation, J.L.; Writing—review and editing, M.M, V.U. and L.L.; Visualization, J.L.; Supervision, M.M., V.U. and L.L.; Project Administration, J.L and M.M.; Funding Acquisition M.M and L.L.

Funding: Luhas and Mikkilä thank the Academy of Finland for financial support (ORBIT project 307480).

Acknowledgments: P.J.'s language editing and constructive comments strengthened the argumentation of the work significantly. We are grateful to the four peer-reviewers for their constructive feedback that helps us to strengthen the argumentation.

Conflicts of Interest: The authors declare no conflict of interest. The funders had no role in the design of the study; in the collection, analyses, or interpretation of data; in the writing of the manuscript, or in the decision to publish the results. 


\section{Appendix A}

Table A1. Material used for analysis.

\begin{tabular}{|c|c|c|c|}
\hline Title & Translation & Author & Type of Document \\
\hline $\begin{array}{l}\text { Suomen metsäsektori uudistuu ja } \\
\text { monipuolistuu }\end{array}$ & $\begin{array}{l}\text { Forest sector in Finland reforms and } \\
\text { diversifies }\end{array}$ & [7] & Magazine article \\
\hline $\begin{array}{l}\text { Metsäsektorin suhdannekatsaus } \\
\text { 2018-2019 }\end{array}$ & Forest sector's economic outlook & [12] & Report \\
\hline $\begin{array}{l}\text { Mastering the dynamics of innovation: } \\
\text { How companies can seize opportunities } \\
\text { in the face of technological change }\end{array}$ & & [44] & Book \\
\hline Suomen sahateollisuuden historia & History of the Finnish sawmill industry & [53] & Book \\
\hline Saha & Sawmill & [54] & Book \\
\hline Tervanpoltosta innovaatiotalouteen & $\begin{array}{l}\text { From tar-burning to innovation } \\
\text { economy }\end{array}$ & [56] & Book \\
\hline $\begin{array}{l}\text { Puusta pitkään: puutuotteiden } \\
\text { suunnittelu ja valmistus }\end{array}$ & $\begin{array}{l}\text { Design and production of wood } \\
\text { products }\end{array}$ & [57] & Book \\
\hline Sahatavaratuotanto & Sawmill production & [58] & Book \\
\hline $\begin{array}{c}\text { Tuote- ja teknologiainnovaatiot } \\
\text { muuttivat rajusti suomalaista } \\
\text { paperiteollisuutta 1900-luvun } \\
\text { jälkipuoliskolla }\end{array}$ & $\begin{array}{l}\text { Product and technology innovations } \\
\text { changed Finnish paper industry in the } \\
\text { late 20th century }\end{array}$ & [60] & Report \\
\hline $\begin{array}{l}\text { The fall and the fragmentation of } \\
\text { national clusters: Cluster evolution in } \\
\text { the paper and pulp industry }\end{array}$ & & [62] & Journal Article \\
\hline
\end{tabular}


Table A1. Cont.

\begin{tabular}{|c|c|c|c|}
\hline Title & Translation & Author & Type of Document \\
\hline $\begin{array}{l}\text { Metsäteollisuusyritysten strategiset } \\
\text { kehityspolut: kilpailu, keskittyminen ja } \\
\text { kasvu pitkällä aikavälillä }\end{array}$ & $\begin{array}{l}\text { Strategic pathways of the forest } \\
\text { industry companies: competition, focus, } \\
\text { and growth in middle range timescale }\end{array}$ & {$[64]$} & Book \\
\hline $\begin{array}{l}\text { Metsäteollisuus itsenäisessä Suomessa } \\
\text { 1918-1968: Suomen } \\
\text { Puunjalostusteollisuuden Keskusliitto } \\
\text { 1918-1968 }\end{array}$ & $\begin{array}{l}\text { Forest industry in independent Finland } \\
\text { between 1918-1968: The Central } \\
\text { Association of Finnish Woodworking } \\
\text { Industries between 1918-1968 }\end{array}$ & [65] & Book \\
\hline $\begin{array}{c}\text { Finland's Forest Industry becomes } \\
\text { a global player }\end{array}$ & & [67] & Journal Article \\
\hline $\begin{array}{l}\text { Globalisation and the Finnish forest } \\
\text { sector: on the internationalisation of } \\
\text { forest-industrial operations }\end{array}$ & & [68] & Journal Article \\
\hline $\begin{array}{l}\text { Forest biorefineries-A business } \\
\text { opportunity for the Finnish forest } \\
\text { cluster }\end{array}$ & & {$[71]$} & Journal Article \\
\hline $\begin{array}{l}\text { Tervasta Thermowoodiin- puun } \\
\text { vuosisadat }\end{array}$ & $\begin{array}{c}\text { From tar to thermowood-woods } \\
\text { centuries }\end{array}$ & [75] & Web page \\
\hline Tervanpoltto & Tar-burning & [76] & Newspaper article \\
\hline $\begin{array}{l}\text { Competitive Behaviour and Business } \\
\text { Innovation in the Forest Industry: } \\
\text { Family Firms, Listed Companies and } \\
\text { Cooperatives Compared }\end{array}$ & & [77] & Journal Article \\
\hline $\begin{array}{c}\text { Suomen metsäteollisuuden historia } \\
\text { 1600-luvulta nykypäivään } \\
\text { ainutlaatuisena kirjasarjana }\end{array}$ & $\begin{array}{l}\text { History of the Finnish forest industry } \\
\text { since } 17 \text { th century until nowadays } \\
\text { available as book series }\end{array}$ & [80] & Web page \\
\hline $\begin{array}{l}\text { UPM-Kymmene: metsän jättiläisen } \\
\text { synty }\end{array}$ & $\begin{array}{l}\text { Birth of the forest product industry } \\
\text { leader }\end{array}$ & [81] & Book \\
\hline $\begin{array}{l}\text { Paperin tuotanto ja kulutus mailman } \\
\text { markkinoilla }\end{array}$ & $\begin{array}{l}\text { Paper production and consumption in } \\
\text { the world market }\end{array}$ & [82] & Web page \\
\hline $\begin{array}{l}\text { Aasian merkitys kasvaa } \\
\text { metsäteollisuuden ulkomaankaupassa }\end{array}$ & $\begin{array}{l}\text { Significance of Asia increases in the } \\
\text { forest industry sales }\end{array}$ & [83] & Web page \\
\hline $\begin{array}{l}\text { Suomen metsiä myydään halpana } \\
\text { selluna kiinalaisille: } \\
\text { \&quot;Suomalainen metsäteollisuus saa } \\
\text { syyttää tästä itseään }\end{array}$ & $\begin{array}{l}\text { Finnish forest are sold as cheap pulp to } \\
\text { Chinese: Finnish forest industry can } \\
\text { blame itself }\end{array}$ & [84] & Newspaper Article \\
\hline $\begin{array}{c}\text { Katsaus Suomen } \\
\text { sellutehdasinvestointeihin }\end{array}$ & $\begin{array}{l}\text { Overview of the pulp factory } \\
\text { investments in Finland }\end{array}$ & [85] & Web page \\
\hline
\end{tabular}




\section{Appendix B}

Table A2. Material used for analysis in Figure 3.

\begin{tabular}{|c|c|c|c|c|c|}
\hline Sector & Title & Translation & Content & Author & $\begin{array}{c}\text { Type of } \\
\text { Document }\end{array}$ \\
\hline \multirow[t]{2}{*}{ Wood product } & Metsän jättiläisen synty & $\begin{array}{l}\text { Birth of the forest } \\
\text { product industry leader }\end{array}$ & $\begin{array}{l}\text { Around the 1900s, there were } \\
\text { carpenter, matchstick and spool } \\
\text { factories, and product } \\
\text { diversification, e.g., ply factories } \\
\text { produced also spoons, forks, ice } \\
\text { hockey sticks and boats }\end{array}$ & [82] & Book \\
\hline & Kaikkea muuta puusta & $\begin{array}{l}\text { Everything else from } \\
\text { wood }\end{array}$ & $\begin{array}{l}\text { Wood-plastic composites are used } \\
\text { e.g., in furniture, guitar and } \\
\text { speaker production }\end{array}$ & [91] & Book \\
\hline \multirow[t]{5}{*}{ Wood panel } & $\begin{array}{c}\text { Kiina jätti kaikki muut } \\
\text { jälkeensä - ennen vuotta } \\
1970 \text { Suomi tuotti neljä } \\
\text { kertaa enemmän vaneria } \\
\text { kuin Kiina }\end{array}$ & $\begin{array}{l}\text { China left behind all the } \\
\text { others; before 1970, } \\
\text { Finland produced four } \\
\text { times more ply than } \\
\text { China }\end{array}$ & $\begin{array}{l}\text { First plywood mill was built in } \\
\qquad 1893\end{array}$ & [92] & $\begin{array}{l}\text { Newspaper } \\
\text { Article }\end{array}$ \\
\hline & Liimapuukäsikirja & Glulam handbook & $\begin{array}{l}\text { Glulam production started in } 1945 \\
\text { due to war reparations }\end{array}$ & [93] & Book \\
\hline & $\begin{array}{c}\text { Vanhoja ja vähän } \\
\text { uudempiakin } \\
\text { rakennusmateriaaleja }\end{array}$ & $\begin{array}{l}\text { Old and new } \\
\text { construction materials }\end{array}$ & $\begin{array}{l}\text { LDF production started in the } \\
1950 \mathrm{~s}\end{array}$ & [94] & Web page \\
\hline & LVL & LVL & $\begin{array}{l}\text { Laminated veneer lumber } \\
\text { production started in the } 1970 \text { s }\end{array}$ & [95] & Presentation \\
\hline & $\begin{array}{l}\text { CLT- tehdas avattiin } \\
\text { Kuhmossa }\end{array}$ & $\begin{array}{l}\text { CLT factory launched in } \\
\text { Kuhmo }\end{array}$ & $\begin{array}{l}\text { Cross-laminated timber } \\
\text { production started in } 2014\end{array}$ & [96] & $\begin{array}{l}\text { Newspaper } \\
\text { Article }\end{array}$ \\
\hline Construction & $\begin{array}{l}\text { Puurakennusten } \\
\text { suunnittelu }\end{array}$ & $\begin{array}{l}\text { Design of wooden } \\
\text { building }\end{array}$ & $\begin{array}{l}\text { Prefab production in the } \\
\text { construction industry started in } \\
\text { the } 1920 \mathrm{~s}\end{array}$ & [97] & Book \\
\hline \multirow[t]{2}{*}{ Energy } & $\begin{array}{l}\text { Pelletti palaa, mutta } \\
\text { vaatimattomasti }\end{array}$ & $\begin{array}{l}\text { Wood pellets burns } \\
\text { modestly }\end{array}$ & $\begin{array}{l}\text { Wood pellet production started in } \\
\text { the } 1990 \mathrm{~s}\end{array}$ & [98] & Web page \\
\hline & $\begin{array}{l}\text { Lajissaan mailman } \\
\text { ensimmäinen- UPM:n } \\
\text { Lappeenrannan } 175 \\
\text { miljoonan euron } \\
\text { biojalostamo aloitti } \\
\text { kaupallisen tuotannon }\end{array}$ & $\begin{array}{l}\text { First in the field in the } \\
\text { world: UPM biorefinery } \\
\text { that cost } 175 \text { million } \\
\text { euros started commercial } \\
\text { production in } \\
\text { Lappeenranta }\end{array}$ & $\begin{array}{l}\text { Forest-based biofuel production } \\
\text { started in } 2014\end{array}$ & [99] & $\begin{array}{l}\text { Newspaper } \\
\text { Article }\end{array}$ \\
\hline \multirow[t]{5}{*}{ Chemical } & $\begin{array}{c}\text { Tervantuotannosta } \\
\text { innovaatiobiotalouteen }\end{array}$ & $\begin{array}{l}\text { Tar production to } \\
\text { innovation bioeconomy }\end{array}$ & $\begin{array}{l}\text { Industrial tar production didn't } \\
\text { become significant part of } \\
\text { chemical industry }\end{array}$ & [56] & Book \\
\hline & $\begin{array}{c}\text { Mäntyöljy on } \\
\text { biopohjaisten tuotteiden } \\
\text { aarreaitta }\end{array}$ & $\begin{array}{l}\text { Tall oil is a treasury of } \\
\text { bioproducts }\end{array}$ & $\begin{array}{l}\text { Tall oil refinement started in the } \\
1910 \mathrm{~s}\end{array}$ & [100] & Web page \\
\hline & Metsän jättiläisen synty & $\begin{array}{l}\text { The birth of the forest } \\
\text { product industry leader }\end{array}$ & $\begin{array}{l}\text { Spirit factory launched during the } \\
\text { WW2 }\end{array}$ & [81] & Book \\
\hline & $\begin{array}{l}\text { Oulun mäntyöljy- ja } \\
\text { tärpättijalosteet }\end{array}$ & $\begin{array}{l}\text { Oulu's tall oil and } \\
\text { turpentine products }\end{array}$ & $\begin{array}{l}\text { In } 1943, \text { substitute production } \\
\text { from turpentine started. In } 1950 \\
\text { tall oil and turpentine distillery } \\
\text { launched in Nuottasaari. }\end{array}$ & [101] & Report \\
\hline & $\begin{array}{c}\text { Suomessa muhii } \\
\text { jättipotti-tehdas eristi } \\
\text { puusta aineen, josta voi } \\
\text { valmistaa } \\
\text { ympäristöystävällisiä } \\
\text { maaleja ja liimoja }\end{array}$ & $\begin{array}{l}\text { Jackpot brews in Finland: } \\
\text { The factory separated } \\
\text { substance that can be } \\
\text { utilized in } \\
\text { environmentally friendly } \\
\text { paint and glue products }\end{array}$ & Lignin production started in 2015 & [102] & $\begin{array}{l}\text { Newspaper } \\
\text { Article }\end{array}$ \\
\hline
\end{tabular}


Table A2. Cont.

\begin{tabular}{|c|c|c|c|c|c|}
\hline Sector & Title & Translation & Content & Author & $\begin{array}{c}\text { Type of } \\
\text { Document }\end{array}$ \\
\hline \multirow[t]{2}{*}{ Pulp } & Liukosellun lupaus & $\begin{array}{l}\text { Promise of dissolving } \\
\text { pulp }\end{array}$ & $\begin{array}{l}\text { Rayon production started in the } \\
\text { end of the 1930s. }\end{array}$ & [103] & Book section \\
\hline & $\begin{array}{c}\text { Nanosellu on } \\
\text { tuleivaisuuden } \\
\text { supermateriaali-niin } \\
\text { lujaa, että sitä on testattu } \\
\text { luotiliivien materiaaliksi }\end{array}$ & $\begin{array}{l}\text { Nanocellulose is a super } \\
\text { material of the future: } \\
\text { it's so strong that it has } \\
\text { tested in bulletproof vest }\end{array}$ & $\begin{array}{l}\text { Nanocellulose production has } \\
\text { been in small-scale }\end{array}$ & [104] & $\begin{array}{l}\text { Newspaper } \\
\text { Article }\end{array}$ \\
\hline \multirow[t]{5}{*}{ Paper } & $\begin{array}{l}\text { Jokapäiväinen } \\
\text { paperimme }\end{array}$ & Our daily paper & $\begin{array}{c}\text { Wood-based papermaking for } \\
\text { a newspaper, wallpaper and } \\
\text { wrapping paper started around } \\
\text { the } 1850 \mathrm{~s}\end{array}$ & [105] & Web page \\
\hline & $\begin{array}{l}\text { Aaltopahvin valmistus ja } \\
\text { jalostus }\end{array}$ & $\begin{array}{l}\text { Corrugated cardboard } \\
\text { production and } \\
\text { processing }\end{array}$ & $\begin{array}{l}\text { Corrugated cardboard production } \\
\text { started in the } 1910 \mathrm{~s}\end{array}$ & [106] & Book \\
\hline & Nestepakkauskartonki & Liquid packaging board & $\begin{array}{c}\text { Liquid packaging board } \\
\text { production started in the early } \\
1950 \mathrm{~s}\end{array}$ & [107] & Report \\
\hline & $\begin{array}{c}\text { Paino- ja } \\
\text { kirjoituspaperien kehitys } \\
\text { 1970-90-luvuilla }\end{array}$ & $\begin{array}{l}\text { Development of graphic } \\
\text { and writing paper } \\
\text { between the 1970s and } \\
\text { the 1990s }\end{array}$ & $\begin{array}{c}\text { Transformation of graphic and } \\
\text { writing paper production towards } \\
\text { high-grade products started in the } \\
\text { 1960s }\end{array}$ & [59] & Report \\
\hline & $\begin{array}{l}\text { Juantehdas: olutpahvista } \\
\text { graafisen kartongin } \\
\text { laatujohtajaksi }\end{array}$ & $\begin{array}{l}\text { Juantehdas: from beer } \\
\text { board to leader in } \\
\text { graphic carton }\end{array}$ & $\begin{array}{l}\text { Carton machine renovated } \\
\text { thoroughly in the 1960s }\end{array}$ & [108] & Report \\
\hline Packaging & Pakkausten historiaa & $\begin{array}{l}\text { History of packaging } \\
\text { products }\end{array}$ & $\begin{array}{l}\text { Trend in disposable packaging in } \\
\text { the } 1960 \mathrm{~s}\end{array}$ & [109] & Web page \\
\hline Machine & $\begin{array}{l}\text { Tervantuotannosta } \\
\text { innovaatiotalouteen }\end{array}$ & $\begin{array}{l}\text { From tar production to } \\
\text { innovation economy }\end{array}$ & $\begin{array}{l}\text { First paper machines produced in } \\
\text { Vyborg in between 1904-1910. }\end{array}$ & {$[56]$} & Book \\
\hline
\end{tabular}

\section{References}

1. European Comission. Bioeconomy. Available online: http://ec.europa.eu/programmes/horizon2020/en/ h2020-sectin/bioeconomy (accessed on 10 January 2019).

2. Bio-Based Industries Joint Undertaking. About BBI JU. Available online: https://www.bbi-europe.eu/about/ about-bbi (accessed on 10 January 2019).

3. European Comission Economy. Available online: https:/ec.europa.eu/knowledge4policy/bioeconomy/topic/ economy_en (accessed on 20 February 2019).

4. Bioeconomy. Finnish Bioeconomy Strategy. Available online: https://www.biotalous.fi/wp-content/uploads/ 2015/01/Suomen_biotalousstrategia_2014.pdf (accessed on 20 February 2019).

5. Bioeconomy. Wood and Forest. Available online: https://www.biotalous.fi/puu-ja-metsa/ (accessed on 10 January 2019).

6. Ministry of Agriculture and Forestry of Finland. Metsäteollisuus Suomessa. Available online: https: $/ / \mathrm{mmm} . \mathrm{fi} / \mathrm{metsat} /$ puun-kaytto/metsateollisuus-suomessa (accessed on 10 January 2019).

7. Hänninen, R. Suomen metsäsektori monipuolistuu ja uudistuu. Available online: http://www.metla.fi/ohjelma/mtu/pdf/ Suomen_metsasektori_monipuolistuu_ja_uudistuu_Hanninen_R.pdf (accessed on 10 January 2019).

8. Lehtonen, P. Metsäteollisuuden Globaali Kilpailykyky. Available online: http://www.ptt.fi/ennusteet/ metsaala/metsasektori-2017-kevat.html (accessed on 10 January 2019).

9. Kivistö, J. Suomen rakennemuutos alueiden näkökulmasta. Available online: https://helda.helsinki.fi/bof/ bitstream/handle/123456789/14416/eurotalous_analyysi_29.pdf?sequence=1 (accessed on 10 January 2019).

10. Luke. Tilastotietokanta. Available online: http://statdb.luke.fi/PXWeb/pxweb/fi/LUKE/LUKE_04Metsa/ ?rxid=37351054-dec1-4d3a-9964-7e4fad7f285c (accessed on 25 January 2019).

11. PTT. Uudet investoinnit ja sahateollisuuden kohentuneet markkinanäkymät suuntaavat metsäsektorin kehitystä. Available online: http://www.ptt.fi/ennusteet/metsaala/metsasektori-2017-kevat.html (accessed on 10 January 2019).

12. Viitanen, J.; Mutanen, A. (Eds.) Metsäsektorin suhdannekatsaus 2018-2019; Luonnonvara-ja biotalouden tutkimus 46/2018; Luonnonvarakeskus: Helsinki, Finland, 2018; 73s; Available online: http:/jukuri.luke.fi/bitstream/handle/10024/542785/ luke-luobio_46_2018.pdf?sequence=5\&isAllowed=y (accessed on 10 January 2019).

13. Hietala, J.; Huovari, J. Puupohjaisen biotalouden taloudelliset vaikutukset ja näkymät. Available online: http://www.ptt.fi/media/img/nostot/tp-184.pdf (accessed on 23 January 2019). 
14. Prime Minister's Office Finland. Kohti biotaloutta: Kapeikot ja ohjauskeinojen suuntaus. Available online: http://julkaisut.valtioneuvosto.fi/handle/10024/160323 (accessed on 24 January 2019).

15. Korhonen, J.; Giurca, A.; Brockhaus, M.; Toppinen, A. Actors and Politics in Finland's Forest-Based Bioeconomy Network. Sustainability 2018, 10, 3785. [CrossRef]

16. Perkins, R. Technological "Lock-In"; International Society for Ecological Economics: Boston, MA, USA, 2003.

17. Unruh, G.C. Understanding carbon lock-in. Energy Policy 2000, 28, 817-830. [CrossRef]

18. Ministry of Economic Affairs and Employment of Finland. Wood-Based Bioeconomy Solving Global Challenges. Available online: http://julkaisut.valtioneuvosto.fi/bitstream/handle/10024/79985/TEM_ oppaat_2_2017_Wood_based_Bioeconomy_Solving_Global_challange_29052017web.pdf?sequence=1\& isAllowed =y (accessed on 26 January 2019).

19. Coenen, L.; Moodysson, J.; Martin, H. Path Renewal in Old Industrial Regions: Possibilities and Limitations for Regional Innovation Policy. Reg. Stud. 2015, 49, 850-865. [CrossRef]

20. Novotny, M.; Laestadius, S. Beyond papermaking: Technology and market shifts for wood-based biomass industries-Management implications for large-scale industries. Technol. Anal. Strateg. Manag. 2014, 26, 875-891. [CrossRef]

21. Smith, A.; Stirling, A.; Berkhout, F. The governance of sustainable sociotechnical transitions. Res. Policy 2005, 34, 1491-1510. [CrossRef]

22. Markard, J.; Raven, R.; Truffer, B. Sustainability transitions: An emerging field of research and its prospects. Res. Policy 2012, 41, 955-967. [CrossRef]

23. Rotmans, J.; Loorbach, D. Complexity and Transition Management. J. Ind. Ecol. 2009, 13, 184-196. [CrossRef]

24. Kemp, R.; Rip, A.; Schot, J. Constructing transition paths through the management of niches BT-Path Dependence and Creation. In Path Dependence and Creation; Lawrence Erlbaum Associates, Inc.: Mahwah, NJ, USA, 2001; pp. 269-299.

25. Arthur, W.B. Competing Technologies, Increasing Returns, and Lock-In by Historical Events. Econ. J. 1989, 99, $116-131$. [CrossRef]

26. Arthur, W.B. Increasing returns and the new world of business. Harv. Bus. Rev. 1996, 74, 100-109.

27. Klitkou, A.; Bolwig, S.; Hansen, T.; Wessberg, N. The role of lock-in mechanisms in transition processes: The case of energy for road transport. Environ. Innov. Soc. Transit. 2015, 16, 22-37. [CrossRef]

28. Kuokkanen, A.; Mikkilä, M.; Kuisma, M.; Kahiluoto, H.; Linnanen, L. The need for policy to address the food system lock-in: A case study of the Finnish context. J. Clean. Prod. 2017, 140, 933-944. [CrossRef]

29. Bjørnåvold, A.; Van Passel, S. The lock-in effect and the greening of automotive cooling systems in the European Union. J. Environ. Manag. 2017, 203, 1199-1207. [CrossRef] [PubMed]

30. Meynard, J.-M.; Charrier, F.; Fares, M.; Le Bail, M.; Magrini, M.-B.; Charlier, A.; Messéan, A. Sociotechnical lock-in hinders crop diversification in France. Agron. Sustain. Dev. 2018, 38, 54. [CrossRef]

31. Stirling, A. A general framework for analysing diversity in science, technology and society. J. R. Soc. Interface 2007, 4, 707-719. [CrossRef]

32. Von Bertalanffy, L. General system theory. N. Y. 1968, 41973, 40.

33. Boulding, K.E. General Systems Theory-The Skeleton of Science. Manag. Sci. 1956, 2, 197-208. [CrossRef]

34. Thurner, S.; Hanel, R.; Klimek, P. Introduction to the Theory of Complex Systems; Oxford University Press: Oxford, UK, 2018.

35. Geels, F.W. Co-evolutionary and multi-level dynamics in transitions: The transformation of aviation systems and the shift from propeller to turbojet (1930-1970). Technovation 2006, 26, 999-1016. [CrossRef]

36. Geels, F.W. Technological transitions as evolutionary reconfiguration processes: A multi-level perspective and a case-study. Res. Policy 2002, 31, 1257-1274. [CrossRef]

37. Geels, F.W. From sectoral systems of innovation to sociotechnical systems: Insights about dynamics and change from sociology and institutional theory. Res. Policy 2004, 33, 897-920. [CrossRef]

38. Dosi, G. Technological paradigms and technological trajectories: A suggested interpretation of the determinants and directions of technical change. Res. Policy 1982, 11, 147-162. [CrossRef]

39. Nelson, R.R.; Winter, S.G. In search of useful theory of innovation. Res. Policy 1977, 6, 36-76. [CrossRef]

40. Geels, F.W. A sociotechnical analysis of low-carbon transitions: Introducing the multi-level perspective into transport studies. J. Transp. Geogr. 2012, 24, 471-482. [CrossRef]

41. David, P. Clio and the Economics of QWERTY. Am. Econ. Rev. 1985, 75, 332-337. 
42. Cairns, R.C. Climate geoengineering: Issues of path dependence and sociotechnical lock-in. Wiley Interdiscip. Rev. Clim. Chang. 2014, 5, 649-661. [CrossRef]

43. Unruh, G.C. Escaping carbon lock-in. Energy Policy 2002, 30, 317-325. [CrossRef]

44. Utterback, J. Mastering the Dynamics of Innovation: How Companies Can Seize Opportunities in the Face of Technological Change; University of Illinois at Urbana-Champaign's Academy for Entrepreneurial Leadership Historical Research Reference in Entrepreneurship; SSRN: Rochester, NY, USA, 1994.

45. Pierson, P. Increasing Returns, Path Dependence, and the Study of Politics. Am. Political Sci. Rev. 2000, 94, $251-267$. [CrossRef]

46. Arthur, W.B. Increasing Returns and Path Dependence in the Economy; University of Michigan Press: Ann Arbor, MI, USA, 1994.

47. Hughes, T.P. The evolution of large technological systems. In The Social Construction of Technological Systems: New Directions in the Sociology and History of Technology; MIT Press: Cambridge, MA, USA, 1987; pp. 51-82.

48. Arrow, K.J. The Economic Implications of Learning by Doing. Rev. Econ. Stud. 1962, 29, 155-173. [CrossRef]

49. Cowan, R. Nuclear power reactors: A study in technological lock-in. J. Econ. Hist. 1990, 50, 541-567. [CrossRef]

50. Safarzyńska, K.; van den Bergh, J.C.J.M. Demand-supply coevolution with multiple increasing returns: Policy analysis for unlocking and system transitions. Technol. Forecast. Soc. Chang. 2010, 77, 297-317. [CrossRef]

51. Kallis, G.; Norgaard, R.B. Coevolutionary Ecological Economics; Elsevier: Amsterdam, The Netherlands, 2010; Volume 69.

52. Rip, A.; Kemp, R. Technological change. Hum. Choice Clim. Chang. 1998, 2, 327-399.

53. Ahvenainen, J. Suomen sahateollisuuden historia; WSOY: Porvoo, Finland, 1984.

54. Kuisma, M. Saha; Kustannusosakeyhtiö Siltala: Helsinki, Finland, 2011.

55. Kuisma, M.; Siltala, S.; Keskisarja, T. Paperin painajainen: Metsäliitto, metsät ja miljardit Suomen kohtaloissa 1984-2014; Kustannusosakeyhtiö Siltala: Helsinki, Finland, 2014.

56. Leppälä, K. Tervanpoltosta innovaatiotalouteen; Avain: Helsinki, Finland, 2012.

57. Loukola, S.; Immonen, P. Puusta pitkään: Puutuotteiden suunnittelu ja valmistus; WSOY: Porvoo, Finland, 2001.

58. Sipi, M. Sahatavaratuotanto, 2nd ed.; Opetushallitus: Helsinki, Finland, 2002.

59. Huuskonen, J.; Pakarinen, H. Paino- ja kirjoituspaperien kehitys 1970- ja 90-luvulla. Available online: https://www.puunjalostusinsinoorit.fi/biometsateollisuus/innovaatiot/4-paperin-ja-kartongin-valmistus/4. 1-paino-ja-kirjoituspaperien-kehitys-1970-90-luvuilla/ (accessed on 11 February 2019).

60. Huuskonen, J.; Palsanen, J.; Sierilä, P.; Levlin, J.-E.; Niemi, T.; Sundquist, J.; Wartiovaara, I. Tuote- ja teknologiainnovaatiot muuttivat rajusti suomalaista paperiteollisuutta 1900-luvun jälkipuoliskolla. Available online: https:/www.puunjalostusinsinoorit.fi/site/assets/files/1356/innovaatioiden_yhteenveto_ 2014_painoversio.pdf (accessed on 11 February 2019).

61. Pakarinen, S.; Mattila, T.; Melanen, M.; Nissinen, A.; Sokka, L. Sustainability and industrial symbiosis-The evolution of a Finnish forest industry complex. Resour. Conserv. Recycl. 2010, 54, 1393-1404. [CrossRef]

62. Järvinen, J.; Lamberg, J.-A.; Pietinalho, L. The fall and the fragmentation of national clusters: Cluster evolution in the paper and pulp industry. J. For. Econ. 2012, 18, 218-241. [CrossRef]

63. Hazley, C. Forest-Based and Related Industries of the European Union-Industrial Districts, Clusters and Agglomerations. Available online: https://www.etla.fi/julkaisut/b160-fi/ (accessed on 15 February 2019).

64. Näsi, J.; Lamberg, J.-A.; Ojala, J.; Sajasalo, P. Metsäteollisuusyritysten strategiset kehityspolut: Kilpailu, keskittyminen ja kasvu pitkällä aikavälillä; Tekes: Helsinki, Finland, 2001.

65. Laurila, J.; Mäkinen, E.; Vuorimaa, H. Metsäteollisuus itsenäisessä Suomessa 1918-1968: Suomen Puunjalostusteollisuuden Keskusliitto 1918-1968; Suomen Paperi- ja Puutavaralehti: Helsinki, Finland, 1968.

66. Lamberg, J.; Laurila, J.; Nokelainen, T. Institutional Path Dependence in Competitive Dynamics: The Case of Paper Industries in Finland and the USA. Manag. Decis. Econ. 2017, 38, 971-991. [CrossRef]

67. Kaar, E.-J. Finland's Forest Industry becomes a global player. Unitas 2000, 72, 14.

68. Aukusti, A. Globalisation and the Finnish forest sector: On the internationalisation of forest-industrial operations. Int. J. Geogr. 2002, 180, 237-250.

69. Lammi, M. Suomen metsäklusteri tienhaarassa; Seppälä, R., Ed.; Tekes: Helsinki, Finland, 2000; Available online: https://docplayer.fi/11124219-Suomen-metsaklusteri-tienhaarassa.html (accessed on 26 January 2019). 
70. Pesonen, P. Innovaatiojohtaminen ja sen vaikutuksia metsäteollisuudessa; VTT Publ. 622; VTT Technical Research Centre of Finland: Espoo, Finland, 2006.

71. Hämäläinen, S.; Näyhä, A.; Pesonen, H.-L. Forest biorefineries-A business opportunity for the Finnish forest cluster. J. Clean. Prod. 2011, 19, 1884-1891. [CrossRef]

72. Mason, J. Qualitative Researching; Sage Publications: Thousand Oaks, CA, USA, 2002.

73. Koskinen, I.; Alasuutari, P.; Peltonen, T. Laadulliset menetelmät kauppatieteissä; Gummerus Kirjapaino; Vastapaino: Tampere, Finland, 2005.

74. Riessman, C.K. Narrative Analysis; University of Huddersfield: Huddersfield, UK, 2005.

75. Finnish Forest Industries. Available online: https://www.metsateollisuus.fi/tiedotteet/tervastathermowoodin-puun-vuosisadat/ (accessed on 26 January 2019).

76. Kaleva. Available online: https://www.kaleva.fi/terva/tervan-tuotanto/tervanpoltto/549986/ (accessed on 26 February 2019).

77. Ojala, J.; Melander, A.; Lamberg, J.-A. Competitive Behaviour and Business Innovation in the Forest Industry: Family Firms, Listed Companies and Cooperatives Compared. In Proceedings of the XIV International Economic History Congress, Helsinki, Finland, 21-25 August 2006.

78. Hildén, M.; Hallanaro, E.-L.; Karjalainen, L.; Järvelä, M. Uusi Luonnonvaratalous: Onko biomassa avain kestävaän kasvuun? Gaudeamus: Helsinki, Finland, 2013.

79. Statistics Finland. Available online: https:/www.stat.fi/tup/suomi90/toukokuu.html (accessed on 14 February 2019).

80. Finnish Forest Industries. Available online: https://www.metsateollisuus.fi/tiedotteet/suomen-metsateollisuudenhistoria-1600-luvulta-nykypaivaan-ainutlaatuisena-kirjasarjana/ (accessed on 10 February 2019).

81. Tuuri, A. UPM-Kymmene: Metsän jättiläisen synty; Otava: Helsinki, Finland, 1999.

82. Finnish Forest Industries. Available online: https://www.metsateollisuus.fi/edunvalvonta/tuotteet/paperintuotanto-kulutus-maailman-markkinoilla/ (accessed on 31 January 2019).

83. Luke. Available online: https:/www.luke.fi/uutiset/aasian-merkitys-kasvaa-metsateollisuudenulkomaankaupassa/ (accessed on 28 February 2019).

84. Yle. Available online: https://yle.fi/uutiset/3-10173727 (accessed on 18 February 2019).

85. Forest Cluster. Available online: http://forestcluster.fi/katsaus-suomen-sellutehdasinvestointeihin/ (accessed on 10 January 2019).

86. Peltoniemi, M. Mechanisms of capability evolution in the Finnish forest industry cluster. J. For. Econ. 2013, 19, $190-205$. [CrossRef]

87. Páez-Avilés, C.; Van Rijnsoever, F.J.; Juanola-Feliu, E.; Samitier, J. Multi-disciplinarity breeds diversity: The influence of innovation project characteristics on diversity creation in nanotechnology. J. Technol. Transf. 2018, 43, 458-481. [CrossRef]

88. D'Costa, A.P. Export Growth and Path Dependence: The Locking-in of Innovations in the Software Industry. Sci. Technol. Soc. 2002, 7, 51-89. [CrossRef]

89. Finnish Forest Association. Available online: https://smy.fi/artikkeli/metsan-arvo-on-noussut-huimastimetsateollisuuden-tuotannon-ei-ratkaisu-on-uusi-tuotanto-ei-sellusovinismi/ (accessed on 1 February 2019).

90. Kaicell Fibers. Available online: http://kaicellfibers.com/biojalostamohanke/kysymyksiae-ja-vastauksia-faq/ (accessed on 10 January 2019).

91. Commitee for the Future. Available online: https://www.eduskunta.fi/FI/tietoaeduskunnasta/julkaisut/ Documents/tuvj_3+2013.pdf (accessed on 10 January 2019).

92. Kouvolan Sanomat. Available online: https://kouvolansanomat.fi/uutiset/talous/2ce8f2f9-c2b6-418f-8022fac4447c0803 (accessed on 10 January 2019).

93. Suomen Liimapuuyhdistys ry \& Puuinfo Oy. Liimapuukäsikirja: Osa 1; Suomen Liimapuuyhdistys ry \& Puuinfo Oy: Alajärvi, Finland, 2014.

94. Rakennustarkkailija. Available online: https://rakennustarkkailija.com/2017/09/22/vanhoja-ja-vahanuudempiakin-rakennusmateriaaleja/ (accessed on 10 January 2019).

95. Levonen, J. Available online: http://www.win-hanke.fi/images/LVL_esitys_Jussi_Levonen_DigiPuuseminaari_Savonia-amk_28.4.2016.pdf (accessed on 20 February 2019).

96. Kainuun Sanomat. Available online: https://www.woodpolis.fi/images/2014/Kainuun_Sanomat_2_12_2014. pdf (accessed on 20 February 2019).

97. Siikanen, U. Puurakennusten Suunnittelu; Rakennustieto: Helsinki, Finland, 1998. 
98. Energiauutiset. Available online: https://www.energiauutiset.fi/tilastouutiset/pelletti-palaa-muttavaatimattomasti.html (accessed on 21 January 2019).

99. Tekniikka \& Talous. Available online: https://www.tekniikkatalous.fi/tekniikka/metsa/2015-01-12/Lajissaanmaailman-ensimmäinen---UPMn-Lappeenrannan-175-miljoonan-euron-biojalostamo-aloitti-kaupallisentuotannon-3258200.html (accessed on 20 February 2019).

100. Bioeconomy. Available online: http://www.biotalous.fi/mantyoljy-on-biopohjaisten-tuotteiden-aarreaitta/ (accessed on 10 February 2019).

101. Niemi, T. Available online: https://www.puunjalostusinsinoorit.fi/biometsateollisuus/innovaatiot/9-sivutuotteet-jaselluloosan-jatkojalosteet/9.9-oulun-mantyoljy-ja-tarpattijalosteet/ (accessed on 10 February 2019).

102. Yle. Available online: https://yle.fi/uutiset/3-10098485 (accessed on 22 February 2019).

103. Viitala, E.-J. Liukosellun Lupaus. Available online: http://www.metla.fi/aikakauskirja/full/ff16/ff163181.pdf (accessed on 22 February 2019).

104. Yle. Available online: https://yle.fi/uutiset/3-10198035 (accessed on 12 February 2019).

105. Niinikoski, E. Available online: http://www.craftmuseum.fi/kiertonayttelyt/jokapaivainen_paperimme/ jokapaivainen_paperimme_kasiohjelma.pdf (accessed on 1 February 2019).

106. Laakso, O.; Rintamäki, T. Aaltopahvin valmistus ja jalostus; Opetushallitus: Helsinki, Finland, 2000.

107. Salste, M. Available online: https://www.puunjalostusinsinoorit.fi/biometsateollisuus/innovaatiot/4-paperinja-kartongin-valmistus/4.12-nestepakkauskartonki/ (accessed on 1 February 2019).

108. Sierilä, P. Available online: https://www.puunjalostusinsinoorit.fi/biometsateollisuus/innovaatiot/4-paperin-ja-kartonginvalmistus/4.14-juantehdas-olutpahvista-graafisen-kartongin-laatujohtajaksi/ (accessed on 1 February 2019).

109. Finnish National Agency for Education. Available online: http://www04.edu.fi/ elintarvikkeidenpakkaaminen/historia.shtml (accessed on 26 February 2019).

(C) 2019 by the authors. Licensee MDPI, Basel, Switzerland. This article is an open access article distributed under the terms and conditions of the Creative Commons Attribution (CC BY) license (http://creativecommons.org/licenses/by/4.0/). 